\section{Size of Trichostrongyle Infective Larvæ in 'Monobacterial' Culture}

IN 1911, Looss ${ }^{1}$ noticed first- and second-stage larvæ of Ancylostoma duodenale ingesting the bacteria 'contaminating' his cultures. He dismissed bacteria as a regular food source, however, because such larvæ "all show the outward signs of insufficient nutrition". Later, it was established by McCoy ${ }^{2}$, and confirmed by Lawrence ${ }^{3}$, that living bacteria were normally necessary for the nutrition of hookworm larvæ. Lapage ${ }^{4}$ also reared the third stages of a number of strongyloid worms, including Trichostrongylus retortaeformis, in broth cultures of coliform bacteria. Although $\mathrm{McCoy}$ made measurements of Ancylostoma caninum larvæ reared in coliform cultures, none of these workers reported any comparisons made between such measurements and those of larvæ grown in ordinary fæcal culture.

Present attempts to obtain standard larvæ of Trichostrongylus retortaeformis by these culture methods reveal a constant reduction in the size of the third stage compared with that achieved in fæeces at the same temperature. This is so whether the bacteria are available as growing colonies on agar or in broth, or merely suspended in Ringer's solution. If, however, the micro-organism is added to autoclaved frees, then a suitable environment seems to be provided, for the larvæ reach their normal 'fæcal' size.

The nematode eggs used in cultures $2-5$ were extracted from the fæces of infected rabbits by centrifugal-salt-flotation, and surface-sterilized with White's solution ${ }^{6}$. The micro-organisms used as food were Bacterium coli Types I and II and an organism intermediate between Bact. coli and Bact. aerogenes (classification as in ref. 7 ).

\begin{tabular}{|c|c|c|c|c|}
\hline Type of culture & $\begin{array}{l}\text { No. of } \\
\text { la:væ } \\
\text { measured }\end{array}$ & $\begin{array}{l}\text { No. of } \\
\text { cultures }\end{array}$ & $\begin{array}{c}\text { Mean } \\
\text { length } \\
\text { third stage }\end{array}$ & $\%$ \\
\hline \multirow{5}{*}{$\begin{array}{l}\text { 1. Fæces (normal) } \\
\text { 2. Fæces (autoclaved } \\
\text { with coliform added) } \\
\text { 3. Monobacterial (agar) } \\
\text { 4. Monobacterial (broth) } \\
\text { 5. Monobacterial } \\
\text { (Ringer's) }\end{array}$} & 100 & 3 & $646 \mu$ & 100 \\
\hline & 50 & 2 & $658 \mu$ & 102 \\
\hline & 250 & 10 & $591 \mu$ & 92 \\
\hline & 50 & 2 & $576 \mu$ & 89 \\
\hline & 50 & 1 & $591 \mu$ & 92 \\
\hline
\end{tabular}

A $t$ test shows that the difference between grand means of $(1+2)$ and $(3+4+5)$ is significant at the $0 \cdot 1$ per cent level of probability

The techniques to which the eggs and larvæ were subjected have been tested to discover whether they affected the size of the latter in an artificial manner. The results of cultures of type 2 show that centrifugalsalt-flotation of the eggs and treatment with White's solution have no depressing effect on larval size. These same cultures show, in addition, that the strain of micro-organism was not at fault, since it was also used in some of the agar, broth and Ringer's solution cultures. Comparison of larvæ grown in monobacterial flasks closed either with cotton plugs or rubber bungs has shown that limitation of oxygen to this extent has no adverse effect on size. The fact that a rubber bung seal encloses sufficient oxygen for complete development is also brought out by the results for culture 2 (see table), in which such a method of closure was adopted. The possible influence of osmotic phenomena on the size of larvæ extracted from fæces by Baermann technique was examined by the measurement of 'monobacterial' larvæ before and after approximately twelve hours subjection to this treatment. No significant increase in size was noted.
Whether the depression in size is due, as Looss supposed, to nutritional deficiencies in bacteria alone is still not established; but the elimination of many procedural factors makes the existence of a nonliving, thermostable, fæcal contribution to larval nutrition a possibility.

\section{P. A. G. WILSON}

Department of Agriculture,

University of Leeds. May 11.

1 Looss, A., Rec. Sch. Med. Cairo, 4 (1911).

2 McCoy, O. R., Science, N.S., 69 (1929); Amer. J. Hyg., 10 (1929). ${ }^{3}$ Lawrence, J., Aust. J. Exp. Biol. Med. Sci., 28 (1948).

Lapage, G., Nature, 131 (1933); 3rd Rep. Dir. Inst. Anim. Path., Cambridge (1933)

s McCoy, O. R., Amer. J. Hyg., 11 (1930).

${ }^{6}$ White, G. F., J. Parasit., 18 (1931).

${ }^{7}$ Ministry of Health, Rep. on Pub. HIth. and Med. Subjs., 71 (rev.) (1939).

\section{Cobalamin Requirement in Chrysophyceae}

ONE of the active principles in aqueous extracts of liver essential for growth of Ochromonas malhamensis ${ }^{1}$ was identified as cobalamin (vitamin $\left.\mathrm{B}_{12}\right)^{2}$. Since this requirement was also found in one or two other chrysomonads, it was suggested that all members of the class might need cobalamin ${ }^{2}$. Some evidence lending further support to this tentative suggestion has recently been obtained from three chrysomonads isolated from brackish supra-littoral pools at Millport : Monochrysis lutheri Droop (Strain 60), Prymnesium parvum Carter (Strain 65) and Syracosphaera elongata nom. prov. (Strain 62).

The three strains, which were grown in bacteriafree culture, required for growth soil or, preferably, liver extract and natural sea water. Both the soil and liver extracts could be replaced completely by cobalamin plus thiamin, the latter apparently having the function of a stimulating substance rather than one for which there was an absolute requirement.

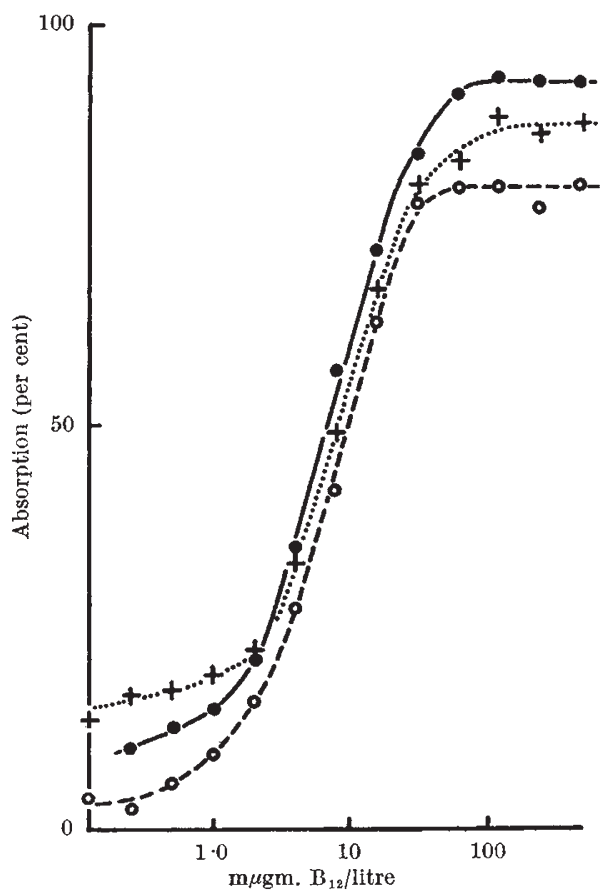

Fig. 1. Response of chrysomonads to doses of cobalamin (Oxo Ltd.). Final yields of cultures measured optically. Continuous
curve, Prymnesium; dotted curve Monochrysis; dashed curve,
Syracosphaera 